\title{
Precautionary Savings of Agents with Heterogeneous Risk
} Aversion

Michele Limosani and Emanuele Millemaci

ISSN: 2031-4892

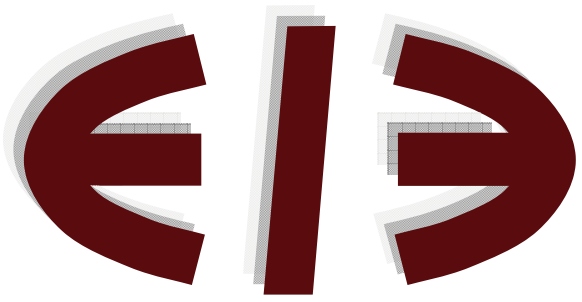

EERI

Economics and Econometrics Research Institute Avenue de Beaulieu 1160 Brussels

Belgium

Tel: +3222988491

Fax: +322 2988490

www.eeri.eu 


\title{
Precautionary Savings of Agents with Heterogeneous Risk Aversion
}

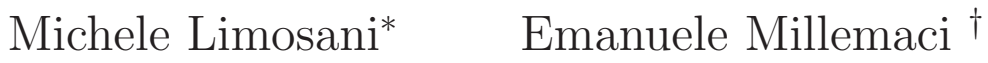

June 19, 2012

\begin{abstract}
This paper focuses on the estimation of the importance of the precautionary motive in the wealth accumulation decision. We use a micro dataset containing information on wealth, a subjective measure of income uncertainty and subjective indicators of risk aversion. The latter makes us possible to account for the fact that more risk averse individuals may select themselves into less risky occupations and, therefore, bias results. Restricting our analysis on male employees heads of households living with partner and children, we find that only a small share of wealth is accumulated for the precautionary motive. Our findings suggest that the more risk averse individuals are those who hold less savings. When heterogeneous risk aversion is not taken into account, estimates do not seem to change significantly. (JEL classification: D10, D91, D84)
\end{abstract}

Key words: Intertemporal choice, Subjective expectations, Precautionary savings, Precautionary wealth, Risk Aversion.

*Universitá di Messina, Dip. di Economia "V.Pareto" (DESMaS). Email: limosani@unime.it.

†Universitá di Messina, Dip. di Economia "V.Pareto" (DESMaS), via Cannizzaro 278, 98122 Messina, Italy. Corresponding author. Tel. +39 (0)906411070 Fax +39 (0)906416275. Email: millemaci@unime.it. 


\section{Introduction}

In the last two decades, many empirical studies have attempted to determine whether, among the reasons for accumulating wealth, individuals consider the precautionary motive as an important factor. However, evidence on this subject has reported mixed results. For instance, Kuehlwein (1991), Dynan (1993), Guiso, Jappelli, and Terlizzese (1992) and StarrMcCluer (1996) find little or no precautionary saving, whereas Carroll (1994), Carroll and Samwick (1997, 1998), Engen and Gruber (1997), and Lusardi (1997, 2000) find evidence of a significant precautionary motive.

Recently, Hurst et al. (2010) point out that aggregating data from business owners and non-business owners may potentially confound the analysis of precautionary savings. This is due to the fact that business owners hold more wealth and face larger labor income risk, regardless of whether a precautionary motive is important. The authors find that treating the two groups of observations separately the precautionary saving motive becomes less important. Following the study of Hurst et al., Fossen and Afschar (2012) do not find significant evidence of precautionary savings once accounting for the endogeneity of the entrepreneurial decision and heterogeneous risk attitudes.

Another estimation issue is the difficulty to find appropriate measures of the noninsurable risk that households face. Some authors have considered the variance of future income. They derived an estimate of the variance of future income by assuming a specific income process and using large datasets on income ${ }^{1}$. However, this approach is sensitive to the presence of measurement error in income, to the choice of the income process used in the empirical estimation, and to how much the consumer knows that the econometrician does not. Another approach is to proxy risk with the variance of consumption, as in Dynan (1993) and Kuehlwein (1991). This is still problematic, since it does not solve the problem of measurement error and depends on the durability of the consumption measure used in the estimation. Other authors have used the occupation of the head of the household as a proxy for uninsurable income risk (Skinner, 1988).

An improvement in the empirical literature is the approach followed by Guiso et al. (1992), consisting in the use of direct survey questions. These authors use the dataset

\footnotetext{
${ }^{1}$ See, among others, Carroll and Samwick (1998), Kazarosian (1997), and Hubbard, Skinner and Zeldes (1995).
} 
of the Italian Survey of Household Income and Wealth (SHIW) containing information on subjective expectations about future income. The SHIW provides information on the distribution of nominal earnings changes in the year following the interview and makes possible to calculate a measure of the subjective variance of earnings. Following a quite similar approach, Lusardi (2000) use the subjective probabilities of job loss provided in the HRS to construct a measure of earnings variance.

In the estimation of the precautionary saving motive, another potential problem is considered, for instance, by Fuchs-Schundeln and Schundeln (2005) and Bartzsch (2008), in two papers relying both on the micro dataset from the German Socio-Economic Panel Study (GSOEP). Fuchs-Schundeln and Schundeln (2005) test the theory of precautionary savings and quantify the importance of self-selection into occupations due to differences in risk aversion. Their findings suggest that self-selection of risk-averse individuals into low-risk occupations is economically important and decreases aggregate precautionary wealth holdings significantly. Bartzsch (2008) adds a direct measure of risk aversion in his estimated model and finds that precautionary saving is statistically significant and economically quite important in explaining net financial wealth. Instead, housing wealth does not seem to be used by subjects as a buffer stock against income uncertainty.

We use the data obtained from the DNB Household Survey provided by Tilburg University to estimate the effect of income uncertainty on wealth accumulation. Similarly to Guiso et al. (1992), we use information on the distribution of nominal next year's expected income to calculate a subjective measure of the variance of expected income.

Moreover, as the use of the distribution of next year's expected income gives an estimate of short term future income uncertainty, one may suspect that this measure is not the most appropriate to proxy the uninsurable income risk a household face and, therefore, affecting precautionary saving decisions. For this reason, following an approach similar to Carroll and Samwick (1998), we also use the observed life-cycle within household income variation as an alternative estimate of income uncertainty.

Finally, we seek to address the potential estimation bias problem - which arises from not considering that subjects may select themselves in different occupations on the basis of their different risk attitudes - by including direct information on the subjects' risk aversion.

We find that, in line with theoretical predictions, precautionary saving is increasing with 
income risk and permanent income. However, the precautionary saving motive accounts only for a small share (0.98\%-3.64\%) of the net wealth that agents hold. This result is stable over different aggregates of wealth and degrees of liquidity. Moreover, our findings suggest that the more risk-averse individuals are those who hold less wealth and save less. Finally, the inclusion of a risk aversion indicator does not affect significantly estimates of the precautionary saving motive.

The reminder of the paper is organized as follows. Sections 2 and 3 describe the model and the dataset, respectively. Section 4 shows the results and section 5 concludes.

\section{Empirical model and estimation strategy}

Our model follows Carroll and Samwick (1998) in what they examine the buffer-stock model's predictions about the relationship between target wealth and income uncertainty. They find a close to linear relationship between the target wealth-to-income ratio and measures of future income uncertainty:

$$
\log \left(w_{i} / p_{i}\right)=a_{0}+a_{1} u_{i}
$$

where $w$ is an estimate of wealth, $p$ is an estimate of the permanent labor income (that is, the income that the household would earn if there were no transitory shocks), $u$ is an estimate of income uncertainty and the subscript $i$ denotes household $i$. Adding $\log (p)$ to both sides and considering a more general specification, we have

$$
\log \left(w_{i}\right)=a_{0}+a_{1} u_{i}+a_{2} \log \left(p_{i}\right)+a_{3} Z_{i}+a_{4} r_{i}+\eta_{i}
$$

where matrix $Z$ includes a set of demographic controls intended to capture other wealth accumulation motives: age, age squared, and dummies for good health conditions, number of children, time and region. $\eta$ is an error term. Finally, $r$ is to control for risk aversion.

A positive and significant parameter $a_{1}$ would imply evidence in favor of the importance of precautionary saving against future income uncertainty. We also expect a positive and significant coefficient $\left(a_{2}\right)$ on permanent income $p_{i}$.

With reference to the parameter $a_{4}$ on risk aversion $r_{i}$, on one side we would expect 
it to be negative as the more one is risk-averse the more he will insure against negative shocks. On the other side, apart from the precautionary saving motive, we might have a negative correlation because the more risk-averse are likely to choose safer jobs and to buy safer assets, and, therefore, to end up with lower returns and wealth accumulation. To distinguish between these two potential opposite directions of causality, we also consider a slight different specification where on the right hand side of equation (2) a term of interaction between income risk and risk aversion is included. If this term of interaction were positive and significant, we could accept the hypothesis that the more risk-averse insure more against negative background risks.

The permanent income represents the component of income that the household would earn in the absence of idiosyncratic shocks. An estimate of the permanent labor income $p_{i}$ can be derived following the approach of Fuchs-Schundeln and Schundeln (2005). We detrend the family labor income by dividing it through the average income of all households in the corresponding survey year. Next, we calculate the average de-trended household income for every household over all available observation years starting in 1995. Permanent income equals the product of this average de-trended household income with the average income of all households within each survey year.

As permanent income is obtained by separating observed income into permanent and temporary parts, it is subjected to measurement error, especially in the cases of those households that we only observe for a few years. Therefore, we instrument permanent income using interaction terms of education dummies ${ }^{2}$ with age to allow for education specific age-income profiles. We perform either the two stages least squares (2SLS) estimator and the limited information maximum likelihood (LIML) estimator. The latter has the advantage to assure good precision even for small sample size ${ }^{3}$. Wald tests of overidentifying restrictions is used to assess the validity of the instruments. Moreover, the robust Kleibergen-Paap Wald rk F statistics (or the rule-of-thumb value of 10 suggested by Staiger and Stock, 1997) is compared to the critical values for the Cragg-Donald F-statistic compiled by Stock et al. (2002) to verify that instruments are not weakly correlated with

\footnotetext{
${ }^{2}$ Included educational dummies are primary, pre-vocational, pre-university, apprentice, vocat. college and university.

${ }^{3}$ LIML is approximately unbiased in the sense that the median of its sampling distribution is generally close to the population parameter being estimated (Anderson et al., 1982; Angrist and Krueger, 2001).
} 
endogenous variables.

The recent findings of Hurst et al. and Fossen and Afschar on the estimation problems arising when using data of either business owners and non-business owners suggest us not to pool these two categories together in our analysis. As the DHS dataset contains only few observations of self-employed individuals, we restrict our analysis to the employees, which should be less subjected to income risk and hence hold less wealth for the precautionary motive.

Following Carroll and Samwick (1998) and Hurst et al., our attention is on heads of households aged 26 to 50 in the year in which the wealth is measured. As for individuals within this age range labor income is the major noncapital source of income, labor income risk is likely to be the most important risk faced.

As we suspect that men and women may have a different sense on precautionary saving and given that most of the heads of households are male, we decided to restrict our analysis on men. Moreover, we decided to focus on the standard family type composed by two parents and one or more children. This restriction is due to the fact that the types of uninsurable risk to be taken into account may differ significantly when referring to other types of cohabitation ${ }^{4}$.

We consider the years between 1995 and 2010 and pool them together to increase the number of observations accounting in estimates for the between years correlation of the same head of household data.

To quantify the amount of precautionary savings based on the estimated parameters, we follow the literature and compare the predicted net worth of households with the simulated net worth they would hold if they all faced no income risk. A prediction of $W_{i}^{*}$, obtained by setting the households income risk $u_{i}=0$ can be interpreted as the amount that households would accumulate if they did not face any uninsurable risk. The average percentage share of total net worth explained by precautionary saving in the sample is then given by

\footnotetext{
${ }^{4}$ For instance, other than labor income risk, an important source of non-insurable risk may be the separation from the cohabitant or having the first child for a couple without children.
} 


$$
\frac{\sum_{i=1}^{N} \hat{W}_{i}-\sum_{i=1}^{N} \hat{W}_{i}^{*}}{\sum_{i=1}^{N} \hat{W}_{i}^{*}} * 100
$$

\section{Data}

For the empirical implementation of the model, a micro dataset containing detailed information on wealth accumulation, income uncertainty and subjective risk aversion is needed. For this purpose, we use data from the DNB Household Survey (DHS), which since 1993 has been part of a project started and administered by CentER, a research institute at the University of Tilburg. ${ }^{5}$

Similarly to Guiso et al. (1992), our measure of income uncertainty is given by the variance of next year's expected income. Our estimation of variance is obtained on the basis of the self-reported information on the agent's probability distribution over the next year income expectation. The data on such information are collected by a module that is similar to the one adopted in the Survey of Economic Expectations (SEE), and discussed in Dominitz and Manski (1997).

In the DHS, the respondents are first asked to answer two questions about the range in which their family income is expected to fall in the next twelve months; the precise wording, translated into English by CentER, is the following: What do you expect to be the lowest (highest) total net income your household may realize in the next 12 months? After answering these questions the interview software determines four income thresholds by means of the following algorithm: threshold th $=Y_{\min }+0.2 \kappa\left(Y_{\max }-Y_{\min }\right)$ and $\kappa=$ $1, \ldots 4$. Then, the respondents are asked to report the percent chance that their net family income will be between $Y_{\min }$ and each threshold. The precise wording of the question is as follows: What do you think is the probability that the total net income of your household will be less than threshold $k$ in the next 12 months? Please fill in a number between 0 to $100 .{ }^{6}$ After division by 100, we obtain 4 point values, corresponding to the thresholds, for the subjective cumulative distribution function of next year's net family income. The unique

\footnotetext{
${ }^{5}$ Since 2003, the project is managed in collaboration with De Nederlandsche bank (DNB).

${ }^{6}$ The percent chance of $y<=y_{\max }$ is not asked and it is implicitly assumed to be 100 .
} 
assumption that we need to make is on the subjective distribution of the respondents. Because of the structure of the questionnaire, we decided to use the beta distribution as it has bounded support. The estimation of its parameters is made by non-linear least squares $^{7}$.

For what concerns wealth, there is no correct definition but rather measures that are more or less useful depending on the purposes. Table 1 presents all the components of wealth that have been collected in the panel. These data have been reported by the agent in the questionnaires on assets and liabilities and accommodation and mortgages and then aggregated into a dedicated data set. If the respondent declared ownership of a particular asset but didn't report its value, he was asked to choose among several value intervals. If he choose a range, the medium value of the range is imputed, otherwise no value is reported.

\section{[Table 1 About Here]}

In our empirical analysis we consider three estimates of wealth, $W_{i}$. The first estimate $\left(W_{i}^{1}\right)$ includes the most liquid assets and liabilities: savings, checking accounts, bonds, stocks and debts:

$$
W_{i}^{1}=\sum_{i=1}^{20} B_{i}-\sum_{i=1}^{8} S_{i}
$$

Respect to $W_{i}^{1}$, the second estimate of wealth $\left(W_{i}^{2}\right)$ adds all durable goods:

$$
W_{i}^{2}=\sum_{i=1}^{20} B_{i}+\sum_{i=21}^{24} B_{i}-\sum_{i=1}^{8} S_{i}
$$

The third estimate of wealth $\left(W_{i}^{3}\right)$ also includes real estates and mortgages ${ }^{8}$ :

$$
W_{i}^{3}=\sum_{i=1}^{20} B_{i}+\sum_{i=21}^{24} B_{i}+B_{25 b p}-B_{25 m}+B_{26 a v}-B_{26 m}+B_{27 a v}-B_{27 m}-\sum_{i=1}^{8} S_{i}
$$

\footnotetext{
${ }^{7}$ Data containing information on the distribution of the subjective next year income expectation have been used in a number of other papers. See, for instance, Giamboni et al. (2007), Limosani and Millemaci (2011) and Kapteyn et al. (2009).

${ }^{8}$ The durable goods values are self-reported estimates of their current market value. $B_{25 b p}$ is the buying price of the first house. The second house $\left(B_{26 a v}\right)$ and the other real estates $\left(B_{27 a v}\right)$ are self-reported current market values.
} 
To distinguish between these three estimates of wealth is important because it allows us to understand if income risk affect the amount of wealth to accumulate or just asset allocation. For instance, if we found significant precautionary savings with using the first or the first two definitions of wealth $\left(W_{i}^{1}\right.$ and $\left.W_{i}^{2}\right)$ but not with the total wealth estimate $\left(W_{i}^{3}\right)$, we should conclude that uninsurable income risks affect asset allocation, stimulating households to hold a greater share of wealth in more liquid assets than housing.

The estimate of realized income we use is the net labor income measure provided by CentER. It is obtained using the self-reported labor income level or imputing the midpoints of the indicated income intervals, if only the second information is provided by respondents.

\subsection{Subjective estimate of risk aversion}

In what follows we focus our analysis on the description of measures for individual risk aversion and on how they correlate with observable characteristics and demographics.

We use information from the section on economic and psychological concepts of the DHS questionnaire. In the part that contains statements concerning saving and taking risks, respondents are asked to indicate to what extent they agree or disagree, using a scale from 1 (totally disagree) to 7 (totally agree), on the basis of their personal opinion or experience. Specifically, we think that the statement "I think it is more important to have safe investments and guaranteed returns, than to take a risk to have a chance to get the highest possible returns" (RA1) may contain information on the degree of respondents' risk aversion ${ }^{9}$. As a comparison, in our empirical analysis, we use two other answers of the questionnaire, correlated with the individual attitude toward risk. The first is a statement to which respondent is asked to respond following the same instructions as for the statement above: "I am prepared to take the risk to lose money, when there is also a chance to gain

\footnotetext{
${ }^{9}$ It is encouraging that, in a field experiment with real money at stake, based on a representative sample of 450 subjects, Dohmen et al. (2011) found that the survey measures of the willingness to take risks used in the SOEP are good predictors of actual risk-taking behavior. Moreover, in a recent study whose empirical analysis makes use of our same subjective risk aversion measures, Kapteyn and Teppa (2011) find results suggesting that such a-theoretical intuitive ad hoc measures for risk aversion are more powerful in explaining portfolio choice than theory based, but complicated, risk tolerance measures. See also Barsky et al. (1997) for additional evidence on risk aversion based on survey responses to hypothetical situations.
} 
money" (RA2). Finally, we consider the following question: "What would you say was the risk factor that you have taken with investments over the past few years?". Respondents are asked to choose among these five following answers, ordered for increasing risk loving behavior: 1)I have taken no risk at all; 2) I have taken small risks every now and then; 3) I have taken some risks; 4) I have sometimes taken great risks; 5) I have often taken great risks $(\mathrm{RA} 3)^{10}$. RA1, RA2 and RA3 are similarly correlated one to each other with the quite large correlation coefficients of about 0.45 .

Ordered logit regressions of these three estimates of risk aversion on net total wealth, family income, age, age squared, dummies for employee, civil servant, educational attainment, gender, number of children, type of cohabitation, region and year are reported in Table $3^{11}$. We also include a dummy for the economic and financial downturn that hit European countries in the years 2008-2010 to understand whether the crisis determined an increase of risk aversion due to its psychological effects (Malmendier and Nagel, 2011; Guiso et al., 2011), other than those that can be explained by wealth, income, labor market condition or one of the other factors we control for.

\section{[Table 3 About Here]}

Net total wealth is always negative and statistically significant. This result is not surprising as the consensus view is that risk aversion should decline with wealth and risk tolerance should increase with household resources, suggesting the inadequacy of assuming a constant absolute risk aversion (CARA) utility function, like quadratic or exponential utility (Guiso and Paiella, 2008).

Family income appears to be negatively correlated with risk aversion. One explanation is that more risk-averse individuals earn less because they choose safer jobs, but we cannot rule out the other explanation that low earnings determine more risk aversion. Civil servant, employee, women and less educated are associated to more risk aversion than private sector employee, self-employed, men and more educated, respectively. Age, type of cohabitation, number of children and region do not seem correlated with our estimates of risk aversion. These results seem in line with previous evidence on determinants of risk aversion

\footnotetext{
${ }^{10}$ RA2 and RA3 have been modified according to RA1 in order to all imply that increasing values suggest increasing risk aversion.

${ }^{11}$ OLS estimation results are very similar and are available upon request from the authors.
} 
(for instance, Guiso and Paiella, 2008, and, with regard to gender differences, Eckel and Grossman, 2008a, 2008b, Ball and Eckel, 2010, and Sapienza et al., 2009).

Figure 1 gives us a descriptive view of the mean and the standard deviation of the three risk aversion indicators over the years 1995-2010. We observe some degree of heterogeneity between indicators in their mean trajectories. RA1 and RA2 show an increasing trend since 2007, while RA3 follows a more irregular trajectory. The dummy on the 2008-2010 economic crisis is statistically significant (and negative) only in the regression where RA3 is the dependent variable. Such evidence of nonsignificant or negative correlation suggests that Dutch households did not report a significant excess of reaction to the crisis.

[Figure 1 About Here]

\subsection{Descriptive analysis}

Summary statistics are reported in Table 2. The 16 years pooled cross-sections of the sample of heads with ages 26-50 give a total size of 16,072. Predictably, the response rates to the questions on income expectations and taking risks were lower, determining a reduction to about a half the number of usable observations. Moreover, as our main results are obtained from regressions over male heads of households with partner and children, the final sample size restricts up to 2,329 observations depending on the specification estimated. As expected, housing wealth is by far the most important component of wealth, accounting for more than $80 \%$ of total net wealth on average $\left(\left[\overline{W^{3}}-\overline{W^{2}}\right] / \overline{W^{3}}\right)$. The two estimates of permanent income show similar distribution parameters and both have means close to the actual income mean. The average reported scores of RA1 and RA2 are about 4 and 5 (st. dev. 1.97 and 1.58), respectively. Males are about $80 \%$. The average age for the sub-sample consisting of individuals which are more than 25 and less than 51 is 39 years. The $86 \%$ of the heads of this sample are employees while only $5 \%$ are self-employed and the remaining subjects are unemployed, pensioners or students. The $52 \%$ of the heads have partner and children.

\section{[Table 2 About Here]}

Figure 2 reports the average time trends of the three estimates of wealth $W_{i}^{1}, W_{i}^{2}$ and $W_{i}^{3}$, and of the family net labor income (expressed in logs), for heads of ages 26-50. We 
observe a negative shock in years 1999-2000 for all estimates of wealth that, as pointed out by Kapteyn et al. (2009), may be due to the fact that in 2000 the technology used for the interviewing of respondents was thoroughly modernized. We do not observe any significant negative effect on wealth and income in the years of the economic and financial downturn (2008-2010). Instead, all aggregates of wealth and family labor income seem to follow a positive time trend that do not interrupt in the years of the recent housing bubble and financial crisis.

\section{[Figure 2 About Here]}

\section{Results}

In this section we show main results from the estimation of various specifications of eq. (2) in order to explore whether and to what extent the precautionary motive is important in explaining households saving decisions.

Firstly, we estimate eq. (2) by using three alternative estimators - the log-linear least squares method (LLS), the limited information maximum likelihood (LIML) and the two stages least squares (2SLS)- to understand how results vary. For each case, we consider the three previously defined estimates of net wealth $\left(W_{i}^{1}, W_{i}^{2}\right.$ and $\left.W_{i}^{3}\right)$. Results, which are reported in Table 4, suggest that results are not very sensitive to the choice of the estimator. The parameter on $p_{i}$ is smaller when we use LLS rather than the other two estimators, while the parameter on $u_{i}$ is a little more negative. Once reassured that results are not driven from the kind of estimation technique chosen, let's focus on the analysis of estimated parameters. Parameters $a_{1}$ and $a_{2}$-associated to permanent income and income variance - have the expected sign and are significant at conventional levels (in the very most cases at $1 \%)$. The parameter on risk aversion $\left(a_{4}\right)$ is negative and significant at $1 \%$ with 7 specifications out of 9 , suggesting that the more risk averse individuals hold less wealth. To understand whether the hypothesis that the more risk-averse hold more precautionary wealth to insure against negative shocks, we add a term of interaction between risk aversion and income variance. The coefficient on the interaction term is always positive but small and nonsignificant at conventional levels ${ }^{12}$. More analysis on the relationship between

\footnotetext{
${ }^{12}$ For the sake of brevity, these results are not reported here but are available upon request from the
} 
precautionary saving and risk aversion will be presented in section 4.2.

\section{[Table 4 About Here]}

While using the first two estimates of wealth as the dependent variable, estimates are very similar, using specification the total net worth $\left(W_{i}^{3}\right)$ we obtain slightly smaller values of $a_{2}$ and slightly larger values of $a_{1}$, and, with the LIML estimator, $a_{4}$ is not statistically significant at conventional levels.

Reported values of the Shea's partial R-squared and the Kleibergen-Paap robust rk Wald F statistic suggest that excluded instruments are satisfactory correlated with the endogenous permanent income variable ${ }^{13}$.

The inclusion in equation (2) of an indicator for individual risk aversion allows us to control for the possible source of bias that more risk-averse individuals may choose less risky jobs and face less income uncertainty. This variable appears to enter negatively in the equation of wealth. To explore how the inclusion of a risk aversion indicator affects precautionary saving estimates, we compare the LIML estimator results of regressions including a risk aversion indicator (specification I) with results of regressions not including a risk aversion indicator (specification II). One may expect that the omission of $r_{i}$ could lead $a_{1}$ to a downward bias and, hence, precautionary saving to appear less important. Instead, we find that the income risk is still positive and significant with parameter values slightly larger rather than smaller.

\section{[Table 5 About Here]}

For all specifications whose results are reported in Tables 4 and 5, the estimate of precautionary saving obtained using the expression (3) gives very low values comprised between 0.98 and 1.2. This evidence is in line with results of a number of other studies, such as the recent paper of Hurst et al. (2010), which attributes the previously estimated large levels of precautionary saving to the spurious correlation induced by business-owners observations.

authors.

${ }^{13} \mathrm{~A}$ problem of weak instruments would occur for values of the Kleibergen-Paap robust rk Wald $\mathrm{F}$ statistic under the critical values compiled by Stock et al. (2002). Instead, for all our estimates the statistic is significantly greater than such thresholds. 


\subsection{Other estimates of the precautionary saving motive}

In this section, we present some other estimates of the precautionary saving motive and discuss other econometric issues.

To understand how results reported in the section above are sensitive to the estimate of permanent income, we consider an alternative estimate that is the average net labor income computed on all years of each head of household. Similarly, we consider an alternative estimate of income risk, which follows one approach of Carroll and Samwick (1998). We compute the within group variance of the log of income, i.e. the variance per household as we observe income over time. Finally, we replace the first (RA1) with the other two risk aversion indicators introduced in section 3 (RA2 and RA3).

\section{[Tables 6-7 About Here]}

Results of the model with the three above described variations are reported in Tables 6 and 7. The new estimates of permanent income and risk aversion do not differ from the previous. A variation in the parameter value is observed for income variance as the new measure considers the variance of the log of income rather than the variance of income. Moreover, with this new variable, we obtain a slightly higher estimate of precautionary savings, ranging between 2.55 and $3.64 \%$ of wealth.

As we use logs, those individuals who reported zero or negative wealth - which accounts for $8-12 \%$ of observations depending on the estimate of wealth considered - were excluded from the sample. The exclusion of such observations may bias estimates. For instance, a household exposed to high income risk may get hit by a negative shock. This negative shock may push this household toward negative wealth holdings even if the preshock household decision was to hold a positive amount of wealth for the precautionary motive, determining their exclusion from the regressions that use logs. To overcome this potential problem, we consider also a specification where the dependent variable is the wealth to permanent income ratio, hence including those reporting negative or zero net wealth ${ }^{14}$. Results from these estimates differentiate somehow from those reported above -

\footnotetext{
${ }^{14}$ Alternatively, we have set to zero the log of wealth of observations reporting zero as wealth. Moreover, to compare results, we considered the level of wealth in place of the log of wealth to retain all negative and zero observations at the cost of more possible bias from outliers that we addressed by excluding the extreme values of the distribution.
} 
statistically significant but small coefficient on income risk with the two larger aggregates of wealth- but substantially confirm that precautionary saving is not very important in wealth accumulation decisions.

When we relax restrictions on male heads and type of cohabitation, we obtain quite similar results. Income risk has still small coefficients, which here become nonsignificant with the second and the third estimates of wealth ${ }^{15}$.

As a further check of robustness, we wish to understand whether the low estimated importance of the precautionary saving motive can be driven by the fact that we only consider answers to questions about family income from heads of households, while the other eventual income earners are not taken into consideration. To address this, we restrict the sample to singles and find that results (which are available upon request) are again quite similar to the previous. We find small but statistically significant coefficients on income variance with the first and the second estimate of wealth. This evidence seems in support to the hypothesis that our estimate of precautionary saving is not largely biased from not considering the self declarations of the other income earners in our empirical analysis.

\subsection{Precautionary saving using the saving equation}

In this section, as a check for robustness, we estimate the precautionary saving motive using the following equation of saving ${ }^{16}$ :

$$
\log \left(s_{i}\right)=\theta_{0}+\theta_{1} u_{i}+\theta_{2} \log \left(y_{i}\right)+\theta_{3} Z_{i}+\theta_{4} r_{i}+\theta_{5} \log \left(w_{i}\right)+\epsilon_{i}
$$

where $s_{i}$ is saving and $y_{i}$ is an estimate of current income. One advantage of estimating this equation is that one can account for the log of current level of wealth when trying to

\footnotetext{
${ }^{15}$ Tables on these regressions are not reported and are available upon request from the authors.

${ }^{16}$ We use respondent's answers on self reported family savings.Respondents are expected to report the amount of money put aside by choosing one of seven predetermined classes. Out of this information we have constructed a variable by taking the midpoints of each class. Since the last interval is right censored, no midpoint can be calculated. To overcome this problem, we assume that the highest bound corresponds to $€ 100,000$. For those who declared not to have put money aside in the last year, we impose zero as the value of $\log$ of saving.
} 
estimate precautionary saving. We expect that saving is positively correlated with income and income risk.

In Table 8, we report results from estimating equation (7) for all three estimates of wealth and all three risk aversion indicators we defined. Coefficients on log of wealth and log of income are all positive and significant at conventional level. Risk aversion indicators are always negative and statistically significant. This result suggests that the more riskaverse heads save less money than the others, other than holding less wealth. Coefficients on the variance of expected income are positive but never statistically significant. This finding does not seem to contradict our previous evidence of low importance of the precautionary saving motive in Dutch household decisions ${ }^{17}$.

\section{[Table 8 About Here]}

\section{Conclusion}

Many empirical studies have attempted to determine whether wealth accumulation is significantly attributable to precautionary saving. However evidence regarding precautionary saving is mixed.

We have used the data obtained from the DNB Household Survey provided by Tilburg University to estimate the precautionary motive in the wealth accumulation decision. This dataset contains information on the distribution of nominal income in the year following the interview and made us possible to calculate a measure of the subjective variance of income. Furthermore, the dataset contains information that was used as estimation of the subjects' risk aversion. As subjects may select themselves in different occupations on the basis of their different risk attitudes, the availability of a direct measure of the degree of subjects' risk aversion made us possible to address such estimation problem.

Our findings suggest that precautionary motive has a statistically significant but small role in wealth accumulation decisions. It seems to account only for 1-3.6 \% of the households wealth accumulation. Moreover, we have not found that the omission of risk aversion

\footnotetext{
${ }^{17}$ Other specifications where a dummy to account for household liquidity constraints and measures of individual discount rates have also been considered but results were similar and therefore not reported.
} 
among the explicative variables bias significantly estimates of the income risk and precautionary saving. Risk aversion appears negatively correlated to wealth accumulation and saving. Finally, the estimates of precautionary savings do not differ significantly for different degrees of wealth liquidity, suggesting that the precautionary motive does not affect allocation between assets of different liquidity.

\section{References}

Anderson, T. W., Kunitomo N. e Sawa T. (1982). "Evaluation of the Distribution Function of the Limited Information Maximum Likelihood Estimator," Econometrica, July, vol. 50, n. 4, pp. 1009-027.

Angrist, J.D. e Krueger A.B. (2001). "Instrumental Variables and the Search for Identification: From Supply and Demand to Natural Experiments." Journal of Economic Perspectives, vol. 15, n. 4, pp. 69-85.

Ball, S., C. Eckel, and M. Heracleous (2010). "Risk Aversion and Physical Prowess: Prediction, Choice and Bias." The Journal of Risk and Uncertainty, 41(3): 167 - 193.

Barsky, R. B., T. F. Juster, M. S. Kimball, and M. D. Shapiro, (1997). "Preference Parameters and Behavioral Heterogeneity: An Experimental Approach in the Health and Retirement Study." Quarterly Journal of Economics, 112(2) : 537 - 79.

Bartzsch, N. (2008). "Precautionary Saving and Income Uncertainty in Germany - New Evidence from Microdata." Journal of Economics and Statistics, vol. 228(1), pages 5-24, February.

Carroll, C. D. (1994). "How Does Future Income Affect Current Consumption?" Quarterly Journal of Economics, vol. 109(1):pp. $111-147$.

Carroll, C. and A. Samwick (1997). "The nature of precautionary wealth." Journal of Monetary Economics, Vol 40, pp 41-71.

Carroll, C. and A. Samwick, (1998). "How important is precautionary saving?" The Review of Economics and Statistics, Vol 80, pp. 410-419.

Thomas Dohmen, A. Falk, D. Huffman, U. Sunde, J. Schupp and G. G. Wagner, (2011). "Individual Risk Attitudes: Measurement, Determinants, And Behavioral Consequences," Journal of the European 
Economic Association, European Economic Association, vol. 9(3), pages 522-550, 06.

Dominitz, J., and C. Manski. (1997). "Using Expectations Data to Study Subjective Income Expectations". Journal of the American Statistical Association, 92, 855-867.

Dynan, K. E., "How Prudent Are Consumers?" (1993). Journal of Political Economy, 101:6, 1104-1113.

Eckel, C. C. and P. J. Grossman, (2008a). "Chapter 113 Men, Women and Risk Aversion: Experimental Evidence." In: Charles R. Plott and Vernon L. Smith, Editor(s), Handbook of Experimental Economics Results, Elsevier, Volume 1, Pages 1061-1073, ISSN 1574-0722, ISBN 9780444826428, 10.1016/S15740722(07)00113-8.

Eckel, C.C. and P.J. Grossman, (2008b). "Forecasting risk attitudes: An experimental study of actual and forecast risk attitudes of women and men." Journal of Economic Behavior \&3 Organization, 68(1), October, 1-17.

Engen, E. and J. Gruber (2001). "Unemployment insurance and precautionary saving." Journal of Monetary Economics, Vol 47, pp. 545-579.

Fossen, F. M. and Rostam-Afschar, D. (2012), "Precautionary and Entrepreneurial Savings: New Evidence from German Households." Oxford Bulletin of Economics and Statistics. doi: 10.1111/j.14680084.2012.00702.x

Fuchs-Schundeln, N. and M. Schundeln (2005). "Precautionary savings and self-selection: evidence from the German reunification experiment", The Quarterly Journal of Economics, Vol. 120, pp. 1085-1120.

Giamboni, Luigi, Emanuele Millemaci, and Robert J. Waldmann, (2007). "Evaluating how predictable errors in expected income affect consumption." MPRA Paper No. 12939. Available at: http://mpra.ub.unimuenchen.de/12939/.

Guiso, L., T. Jappelli, and D. Terlizzese, (1992). "Earnings Uncertainty and Precautionary Saving." Journal of Monetary Economics 30:4, 307-337.

Guiso, L. and M. Paiella, (2008). Risk aversion, wealth, and background risk." Journal of the European Economic Association, 6: 11091150. doi: 10.1162/JEEA.2008.6.6.1109

Guiso, L., P. Sapienza, and L. Zingales, (2011). "Time varying risk aversion," Working paper. 
Hubbard, R. Glenn, Jonathan S. Skinner, and Stephen P. Zeldes, (1995). "Precautionary Saving and Social Insurance," Journal of Political Economy, 103 : 360-399.

Hurst, E., A. Lusardi, A. Kennickell, and F. Torralba (2010), "The Importance of Business Owners in Assessing the Size of Precautionary Savings," Review of Economics and Statistics, 92, pp. 61 - 69.

Kapteyn, A., K. Kleinjans and A. Van Soest (2009). "Intertemporal consumption with directly measured welfare functions and subjective expectations." Journal of Economic Behavior and Organization, 72(1), $425-437$.

Kapteyn, A. and F. Teppa, (2011). "Subjective measures of risk aversion, fixed costs, and portfolio choice." Journal of Economic Psychology, Elsevier, vol. 32(4), pages 564 - 580, August.

Kazarosian, M. (1997), "Precautionary savings - A panel study," The Review of Economics and Statistics, Vol 79, pp. $241-247$.

Kuehlwein, M., (1991). "A Test for the Presence of Precautionary Saving," Economic Letters 37 (1991), $471-475$.

Limosani, M. and E. Millemaci, (2011). "Evidence on excess sensitivity of consumption to predictable income growth," Research in Economics, Elsevier, vol. 65(2), pages 71 - 77, June.

Lusardi, A. (1997). "Precautionary saving and subjective earnings variance". Economics Letters, Vol 57, pp $319-326$.

Lusardi, Annamaria (2000), "Precautionary Saving and the Accumulation of Wealth." Mimeo, Dartmouth College.

Malmendier, U. and S. Nagel (2011), "Depression babies: Do Macroeconomic Experience Affect RiskTaking?", Quarterly Journal of Economics 126, 373416.

Sapienza P. , L. Zingales, D. Maestripieri, (2009). "Gender differences in financial risk aversion and career choices are affected by testosterone." Proceedings of the National Academy of Sciences of the United States of America, USA. 106(36):1526815273.

Skinner, J. (1988). "Risky income, life cycle consumption, and precautionary savings." Journal of Monetary Economics, Vol 22, pp. $237-255$. 
Staiger, D. and J.H. Stock, (1997). "Instrumental variables regressions with weak instruments." Econometrica, $65,557-586$.

Starr-McCluer, M., (1996). "Health insurance and precautionary saving". American Economic Review, Vol. 86, pages $285-295$.

Stock, J. H., J. H. Wright, and M. Yogo, (2002). "A survey of weak instruments and weak identification in generalized method of moments." Journal of Business and Economic Statistics 20: 518 - 529. 
Table 1: Overview of all asset, debt and mortgages components.

\begin{tabular}{l|l}
\hline \hline $\mathrm{B}_{1}$ & Checking accounts \\
$\mathrm{B}_{2}$ & Employer-sponsored saving plans \\
$\mathrm{B}_{3}$ & Savings arrangements, linked to a postbank account \\
$\mathrm{B}_{4}$ & Deposit books \\
$\mathrm{B}_{5}$ & Savings or deposit accounts \\
$\mathrm{B}_{6}$ & Savings certificates \\
$\mathrm{B}_{7}$ & Single-premium annuity insurance policies \\
$\mathrm{B}_{8}$ & Savings or endowment insurance policies \\
$\mathrm{B}_{9}$ & Combined life insurance policies \\
$\mathrm{B}_{10}$ & Pension scheme, not partly paid for by employer \\
$\mathrm{B}_{11}$ & Growth funds \\
$\mathrm{B}_{12}$ & Mutual funds and/or mutual funds accounts \\
$\mathrm{B}_{13}$ & Bonds and/or mortgage bonds \\
$\mathrm{B}_{14}$ & Stocks and shares \\
$\mathrm{B}_{15}$ & Put-options bought \\
$\mathrm{B}_{16}$ & Put-options written \\
$\mathrm{B}_{17}$ & Call-options bought \\
$\mathrm{B}_{18}$ & Call-options written \\
$\mathrm{B}_{19}$ & Money lent out to family or friends \\
$\mathrm{B}_{20}$ & Savings or investments not mentioned before \\
& \\
$\mathrm{B}_{21}$ & Cars \\
$\mathrm{B}_{22}$ & Motorbikes \\
$\mathrm{B}_{23}$ & Boats \\
$\mathrm{B}_{24}$ & Caravans \\
&
\end{tabular}

Note: This table is a reproduction of information contained in the DHS documentation files. 
Table 2: Summary statistics

\begin{tabular}{|c|c|c|c|c|c|}
\hline Variable & Mean & Std. Dev. & Min. & Max. & $\mathbf{N}$ \\
\hline wealth 1 & 6682.8 & 10972.85 & -6696.95 & 60355 & 11112 \\
\hline wealth 2 & 18399.45 & 26518.35 & -5788.5 & 151421.72 & 10994 \\
\hline wealth 3 & 61530.77 & 83282.21 & -1744.49 & 427077.81 & 11017 \\
\hline actual income & 39593.54 & 45688.95 & 0 & 730000 & 16072 \\
\hline permanent inc. 1 & 40041.52 & 41941.76 & 0 & 454131.97 & 16072 \\
\hline permanent inc. 2 & 38307.62 & 38189.94 & 0 & 430000 & 16072 \\
\hline $\operatorname{Var}_{t}^{s u}\left(y_{t+1}\right) \mathrm{I}$ & 6404052.11 & 141427290.25 & 1 & 11098189824 & 9222 \\
\hline $\operatorname{Var}_{t}\left(\ln \left(y_{t+1}\right)\right) \mathrm{II}$ & 0.54 & 2.5 & 0 & 57.44 & 11010 \\
\hline risk aversion ind. (RA1) & 3.98 & 1.97 & 1 & 7 & 8731 \\
\hline risk aversion ind. (RA2) & 4.98 & 1.58 & 1 & 7 & 8774 \\
\hline risk aversion ind. (RA3) & 3.75 & 1.02 & 1 & 5 & 4795 \\
\hline Primary & 0.01 & 0.11 & 0 & 1 & 16072 \\
\hline Pre vocational & 0.18 & 0.38 & 0 & 1 & 16072 \\
\hline Pre university & 0.07 & 0.25 & 0 & 1 & 16072 \\
\hline Apprentice & 0.23 & 0.42 & 0 & 1 & 16072 \\
\hline Vocat. college & 0.29 & 0.45 & 0 & 1 & 16072 \\
\hline University & 0.2 & 0.4 & 0 & 1 & 16072 \\
\hline N. children & 1.17 & 1.21 & 0 & 7 & 16070 \\
\hline good health & 0.59 & 0.49 & 0 & 1 & 16072 \\
\hline gender(male) & 0.79 & 0.41 & 0 & 1 & 16072 \\
\hline age & 39.03 & 6.81 & 26 & 50 & 16072 \\
\hline employee & 0.86 & 0.35 & 0 & 1 & 16072 \\
\hline self-employed & 0.05 & 0.22 & 0 & 1 & 16072 \\
\hline retired & 0 & 0.04 & 0 & 1 & 16072 \\
\hline single & 0.23 & 0.42 & 0 & 1 & 16072 \\
\hline partner,no children & 0.21 & 0.41 & 0 & 1 & 16072 \\
\hline partner and children & 0.52 & 0.5 & 0 & 1 & 16072 \\
\hline children, no partner & 0.04 & 0.19 & 0 & 1 & 16072 \\
\hline 1995 & 0.1 & 0.3 & 0 & 1 & 16072 \\
\hline 1996 & 0.09 & 0.29 & 0 & 1 & 16072 \\
\hline 1997 & 0.08 & 0.27 & 0 & 1 & 16072 \\
\hline 1998 & 0.06 & 0.23 & 0 & 1 & 16072 \\
\hline 1999 & 0.05 & 0.22 & 0 & 1 & 16072 \\
\hline 2000 & 0.06 & 0.25 & 0 & 1 & 16072 \\
\hline 2001 & 0.08 & 0.28 & 0 & 1 & 16072 \\
\hline 2002 & 0.07 & 0.26 & 0 & 1 & 16072 \\
\hline 2003 & 0.07 & 0.25 & 0 & 1 & 16072 \\
\hline 2004 & 0.05 & 0.22 & 0 & 1 & 16072 \\
\hline 2005 & 0.05 & 0.22 & 0 & 1 & 16072 \\
\hline 2006 & 0.05 & 0.22 & 0 & 1 & 16072 \\
\hline 2007 & 0.04 & 0.2 & 0 & 1 & 16072 \\
\hline 2008 & 0.04 & 0.19 & 0 & 1 & 16072 \\
\hline 2009 & 0.04 & 0.19 & 0 & 1 & 16072 \\
\hline 2010 & 0.03 & 0.18 & 0 & 1 & 16072 \\
\hline west & 0.27 & 0.45 & 0 & 1 & 16072 \\
\hline east & 0.21 & 0.41 & 0 & 1 & 16072 \\
\hline south & 0.23 & 0.42 & 0 & 1 & 16072 \\
\hline
\end{tabular}

Note: Summary statistics restricted to the sample of heads with age in the range between 26 and 50. Permanent income I is computed as explained in section 2; permanent income II is computed as explained in section 4.1. 
Table 3: Ordered logit estimates of Risk Aversion indicators on demographic variables

\begin{tabular}{|c|c|c|c|}
\hline & (RA1) & (RA2) & (RA3) \\
\hline \multirow[t]{2}{*}{ family income } & $-3.73 e-06^{* * *}$ & $-1.25 \mathrm{e}-06^{* *}$ & $-9.11 \mathrm{e}-07^{* *}$ \\
\hline & -5.54 & -2.23 & -2.05 \\
\hline \multirow[t]{2}{*}{ Pre university } & $-.43^{* * *}$ & $-.278^{* * *}$ & -.0844 \\
\hline & -3.40 & -2.62 & -0.89 \\
\hline \multirow[t]{2}{*}{ Apprentice } & $-.25^{* * *}$ & -.0742 & -.101 \\
\hline & -2.62 & -0.98 & -1.36 \\
\hline \multirow[t]{2}{*}{ Vocat. college } & $-.529 * * *$ & $-.281^{* * *}$ & $-.206^{* * *}$ \\
\hline & -5.66 & -3.72 & -3.06 \\
\hline \multirow[t]{2}{*}{ University } & $-1.11 * * *$ & $-.588 * * *$ & $-.371^{* * *}$ \\
\hline & -10.70 & -6.76 & -4.94 \\
\hline \multirow[t]{2}{*}{ gender } & $-.885^{* * *}$ & $-.761^{* * *}$ & $-.434^{* * *}$ \\
\hline & -10.27 & -11.27 & -7.32 \\
\hline \multirow[t]{2}{*}{ age } & .0128 & -.00823 & -.0404 \\
\hline & 0.26 & -0.21 & -1.16 \\
\hline \multirow[t]{2}{*}{ age squared } & -.000154 & .000266 & .000416 \\
\hline & -0.25 & 0.53 & 0.95 \\
\hline \multirow[t]{2}{*}{ single } & -.166 & .283 & .416 \\
\hline & -0.47 & 1.14 & 1.19 \\
\hline \multirow[t]{2}{*}{ partner,no children } & -.13 & .298 & .381 \\
\hline & -0.37 & 1.20 & 1.10 \\
\hline \multirow[t]{2}{*}{ partner and children } & -.209 & .443 & .194 \\
\hline & -0.54 & 1.58 & 0.55 \\
\hline \multirow[t]{2}{*}{ children, no partner } & -.079 & $.538^{*}$ & .194 \\
\hline & -0.19 & 1.76 & 0.53 \\
\hline \multirow[t]{2}{*}{1 child } & .157 & -.193 & .14 \\
\hline & 0.75 & -1.10 & 0.78 \\
\hline \multirow[t]{2}{*}{2 children } & .261 & .0127 & .246 \\
\hline & 1.24 & 0.07 & 1.40 \\
\hline \multirow[t]{2}{*}{3 children } & .0237 & -.203 & .165 \\
\hline & 0.11 & -1.08 & 0.87 \\
\hline \multirow[t]{2}{*}{4 children } & -.0917 & .0257 & .0992 \\
\hline & -0.31 & 0.11 & 0.45 \\
\hline \multirow[t]{2}{*}{ constant } & $5.19^{* * *}$ & $5.61^{* * *}$ & $5.23^{* * *}$ \\
\hline & 5.34 & 7.13 & 7.24 \\
\hline R-squared & 0.086 & 0.065 & 0.074 \\
\hline $\mathrm{N}$ & 8797 & 8843 & 4818 \\
\hline
\end{tabular}

Notes: The table reports Ordered logit estimation results of three subjective estimates of risk aversion ( $R A 1, R A 2$ and $R A 3)$ on family income, age, age squared, dummies for educational attainment, gender, number of children, type of cohabitation, region and year. Standard errors are modified to account for outliers and repeated same individual observations by means of the options robust and cluster of Stata 11.*,**,*** indicate coefficients are significative at 10, 5 and $1 \%$, respectively. 


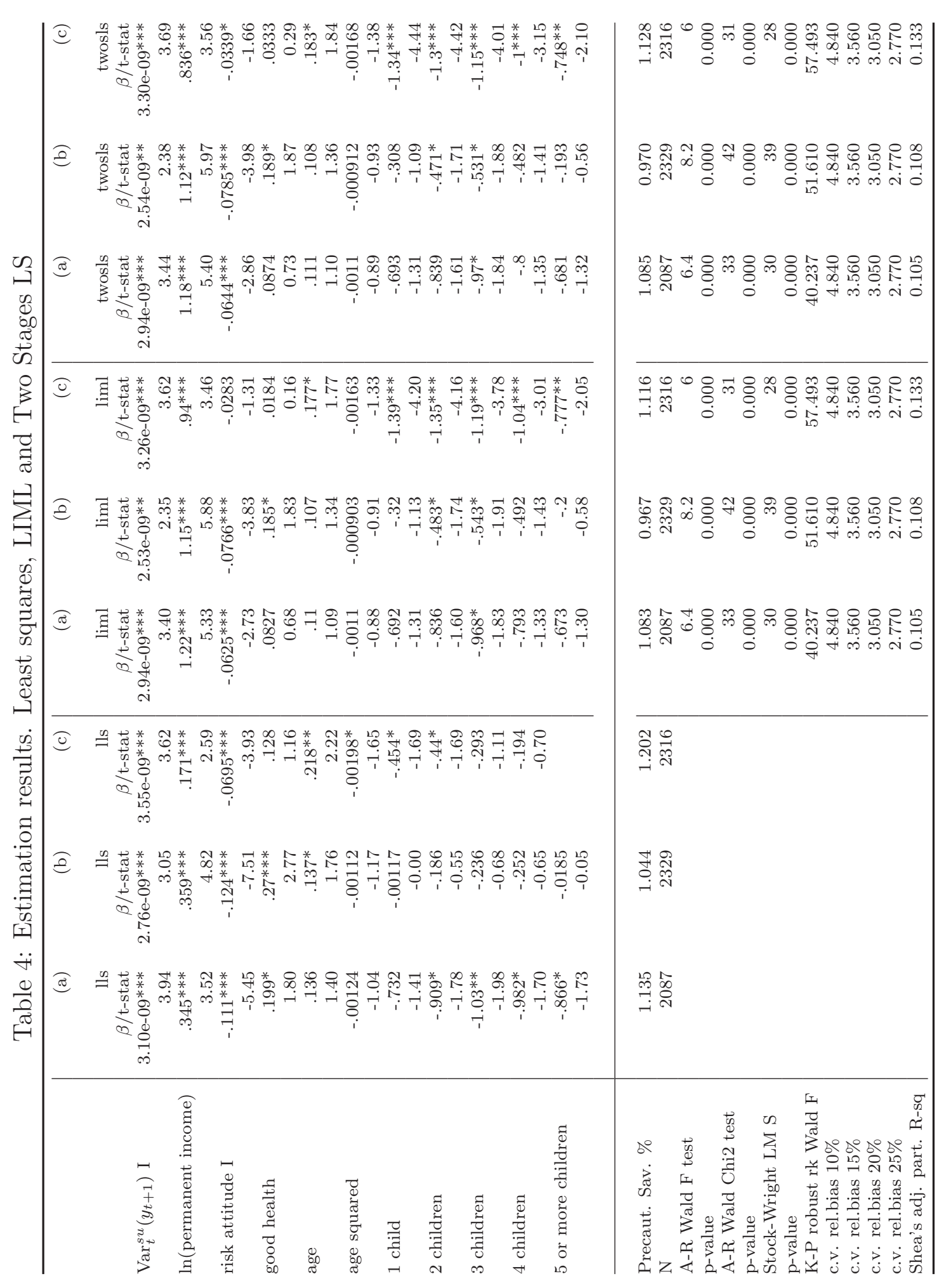

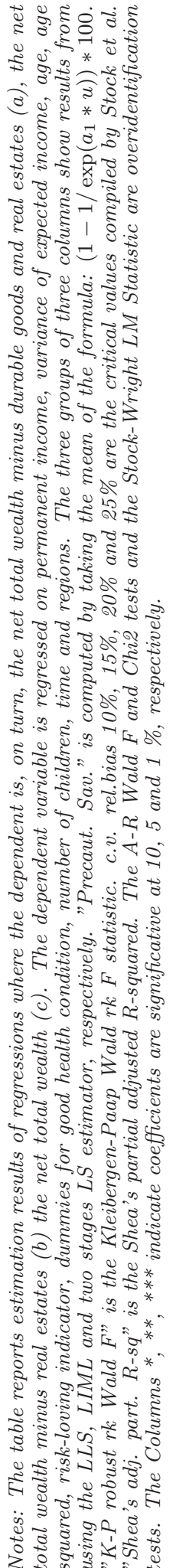


Table 5: Estimation results. Specifications with and without a risk aversion indicator

\begin{tabular}{|c|c|c|c|c|c|c|}
\hline & & & & $Y_{i}^{2}$ & W & \\
\hline & (a1) & (a2) & (b1) & (b2) & (c1) & (c2) \\
\hline & $\beta /$ t-stat & $\beta /$ t-stat & $\beta /$ t-stat & $\beta /$ t-stat & $\beta /$ t-stat & $\beta /$ t-stat \\
\hline $\ln ($ permanent income $)$ & $1.22^{* * *}$ & $1.35^{* * *}$ & $1.15^{* * *}$ & $1.3^{* * *}$ & $.937^{* * *}$ & $.991^{* * *}$ \\
\hline & 5.32 & 6.07 & 5.89 & 6.98 & 3.46 & 3.98 \\
\hline $\operatorname{Var}_{t}^{s u}\left(y_{t+1}\right) \mathrm{I}$ & $2.95 \mathrm{e}-09^{* * *}$ & $3.14 \mathrm{e}-09^{* * *}$ & $2.54 \mathrm{e}-09 * *$ & $2.80 \mathrm{e}-09 * * *$ & $3.28 \mathrm{e}-09^{* * *}$ & $3.37 \mathrm{e}-09 * * *$ \\
\hline & 3.41 & 3.60 & 2.36 & 2.65 & 3.63 & 3.69 \\
\hline risk aversion ind. I & $-.0631^{* * *}$ & & $-.0778^{* * *}$ & & -.0302 & \\
\hline & -2.75 & & -3.91 & & -1.40 & \\
\hline good health & .0788 & .0758 & $.18^{*}$ & $.181 *$ & .0108 & .00741 \\
\hline & 0.65 & 0.62 & 1.78 & 1.76 & 0.09 & 0.06 \\
\hline age & .109 & .109 & .106 & .105 & $.177^{*}$ & $.174^{*}$ \\
\hline & 1.08 & 1.06 & 1.33 & 1.28 & 1.77 & 1.71 \\
\hline age squared & -.00109 & -.0011 & -.000888 & -.000892 & -.00163 & -.00159 \\
\hline & -0.87 & -0.86 & -0.90 & -0.88 & -1.33 & -1.29 \\
\hline 1 child & .0457 & .00371 & .0911 & .035 & $-.459^{* * *}$ & $-.481^{* * *}$ \\
\hline & 0.17 & 0.01 & 0.45 & 0.17 & -2.65 & -2.76 \\
\hline 2 children & -.0985 & -.137 & -.0716 & -.13 & $-.421^{* * *}$ & $-.445^{* * *}$ \\
\hline & -0.40 & -0.53 & -0.37 & -0.64 & -2.61 & -2.73 \\
\hline 3 children & -.23 & -.259 & -.131 & -.178 & -.261 & $-.278^{*}$ \\
\hline & -0.90 & -0.98 & -0.66 & -0.85 & -1.58 & -1.66 \\
\hline Precaut. Sav. \% & 1.087 & 1.147 & 0.967 & 1.057 & 1.121 & 1.149 \\
\hline R-squared & -0.030 & -0.076 & 0.031 & -0.034 & 0.052 & 0.038 \\
\hline $\mathrm{N}$ & 2087 & 2087 & 2329 & 2329 & 2316 & 2316 \\
\hline A-R Wald test & 6.4 & 8.5 & 8.2 & 11 & 6 & 6.5 \\
\hline p-value & 0.000 & 0.000 & 0.000 & 0.000 & 0.000 & 0.000 \\
\hline A-R Wald test & 33 & 43 & 41 & 57 & 31 & 33 \\
\hline p-value & 0.000 & 0.000 & 0.000 & 0.000 & 0.000 & 0.000 \\
\hline Stock-Wright LM S statistic & 30 & 38 & 39 & 51 & 28 & 31 \\
\hline $\mathrm{p}$-value & 0.000 & 0.000 & 0.000 & 0.000 & 0.000 & 0.000 \\
\hline $\mathrm{K}-\mathrm{P}$ robust rk Wald $\mathrm{F}$ & 24.258 & 26.553 & 29.560 & 32.680 & 30.238 & 35.572 \\
\hline c.v. rel.bias $10 \%$ & 4.840 & 4.840 & 4.840 & 4.840 & 4.840 & 4.840 \\
\hline c.v. rel.bias $15 \%$ & 3.560 & 3.560 & 3.560 & 3.560 & 3.560 & 3.560 \\
\hline c.v. rel.bias $20 \%$ & 3.050 & 3.050 & 3.050 & 3.050 & 3.050 & 3.050 \\
\hline c.v. rel.bias $25 \%$ & 2.770 & 2.770 & 2.770 & 2.770 & 2.770 & 2.770 \\
\hline Shea's adj. part. R-sq & 0.105 & 0.121 & 0.108 & 0.127 & 0.133 & 0.153 \\
\hline
\end{tabular}

Notes:The table reports estimation results where the dependent is, on turn, the net total wealth minus durable goods and real estates (a), the net total wealth minus real estates $(b)$ the net total wealth (c). The dependent variable is regressed on permanent income, variance of expected income, age, age squared, risk-loving indicator, dummies for good health condition, number of children, time and regions. Columns with number 1 report estimates obtained by means of the LIML estimator. Respect to columns with number 1, columns with number 2 show results from specifications where the risk aversion indicator is not included. "Precaut. Sav." is computed by taking the mean of the formula: $\left(1-1 / \exp \left(a_{1} * u\right)\right) * 100$. "K-P robust rk Wald F" is the Kleibergen-Paap Wald rk F statistic. c.v. rel.bias 10\%, 15\%, 20\% and 25\% are the critical values compiled by Stock et al. "Shea's adj. part. R-sq" is the Shea's partial adjusted R-squared. The A-R Wald F and Chi2 tests and the Stock-Wright LM Statistic are overidentification tests. *, **, *** indicate coefficients are significative at 10, 5 and $1 \%$, respectively. 
Table 6: Estimation results. Alternative measures of permanent income and income risk

\begin{tabular}{|c|c|c|c|c|c|c|}
\hline & (a1) & (b1) & $(\mathrm{c} 1)$ & $(\mathrm{a} 2)$ & $(\mathrm{b} 2)$ & $(\mathrm{c} 2)$ \\
\hline & $\operatorname{liml}$ & liml & $\operatorname{liml}$ & liml & liml & liml \\
\hline & $\beta /$ t-stat & $\beta /$ t-stat & $\beta /$ t-stat & $\beta /$ t-stat & $\beta /$ t-stat & $\beta /$ t-stat \\
\hline \multirow[t]{2}{*}{$\operatorname{Var}_{t}^{s u}\left(y_{t+1}\right) \mathrm{I}$} & $2.59 \mathrm{e}-09 * * *$ & $2.30 \mathrm{e}-09 * *$ & $3.12 \mathrm{e}-09^{* * *}$ & & & \\
\hline & 4.25 & 2.20 & 4.08 & & & \\
\hline \multirow[t]{2}{*}{$\operatorname{Vart}\left(y_{t+1}\right) \mathrm{II}$} & & & & $.113^{* * *}$ & $.0982^{* * *}$ & $.0683^{*}$ \\
\hline & & & & 2.95 & 2.76 & 1.90 \\
\hline \multirow[t]{2}{*}{$\ln ($ permanent income) } & & & & $1.45^{* * *}$ & $1.3^{* * *}$ & $.974^{* * *}$ \\
\hline & & & & 5.71 & 5.87 & 3.35 \\
\hline \multirow[t]{2}{*}{$\log ($ permanent income) II } & $1.33^{* * *}$ & $1.19 * * *$ & $.818^{* * *}$ & & & \\
\hline & 5.33 & 5.94 & 3.04 & & & \\
\hline \multirow[t]{2}{*}{ risk aversion ind. I } & $-.057 * *$ & $-.0784 * * *$ & $-.0379 *$ & $-.0633^{* * *}$ & $-.0746 * * *$ & -.0265 \\
\hline & -2.42 & -4.04 & -1.78 & -2.95 & -4.02 & -1.25 \\
\hline \multirow[t]{2}{*}{ good health } & .0593 & .151 & .0414 & -.000122 & .123 & .000387 \\
\hline & 0.49 & 1.44 & 0.37 & -0.00 & 1.27 & 0.00 \\
\hline \multirow[t]{2}{*}{ age } & .0889 & .0931 & $.183^{*}$ & .0237 & .00912 & $.182^{*}$ \\
\hline & 0.89 & 1.16 & 1.86 & 0.24 & 0.12 & 1.85 \\
\hline \multirow[t]{2}{*}{ age squared } & -.000784 & -.000685 & -.00163 & -.000121 & .000269 & -.00168 \\
\hline & -0.63 & -0.69 & -1.36 & -0.10 & 0.28 & -1.40 \\
\hline \multirow[t]{2}{*}{1 child } & -.0153 & .0559 & $-.459 * * *$ & -.00541 & .0446 & $-.47^{* *}$ \\
\hline & -0.06 & 0.28 & -2.74 & -0.02 & 0.22 & -2.57 \\
\hline \multirow[t]{2}{*}{2 children } & -.0742 & -.027 & $-.377 * *$ & -.183 & -.157 & $-.462 * * *$ \\
\hline & -0.29 & -0.14 & -2.53 & -0.73 & -0.81 & -2.71 \\
\hline \multirow[t]{2}{*}{3 children } & -.16 & -.0481 & -.202 & -.276 & -.198 & $-.296^{*}$ \\
\hline & -0.62 & -0.24 & -1.30 & -1.08 & -0.99 & -1.73 \\
\hline Precaut. Sav. \% & 0.971 & 0.888 & 1.072 & 3.280 & 2.990 & 2.107 \\
\hline R-squared & -0.009 & 0.065 & 0.113 & 0.029 & 0.092 & 0.081 \\
\hline $\mathrm{N}$ & 2087.000 & 2329.000 & 2316.000 & 2271.000 & 2534.000 & 2510.000 \\
\hline A-R Wald test & 6.409919 & 8.165394 & 6.021359 & 6.866013 & 8.2523 & 5.71649 \\
\hline p-value & $7.3 \mathrm{e}-06$ & $1.4 \mathrm{e}-07$ & .000017 & $2.7 \mathrm{e}-06$ & $1.2 \mathrm{e}-07$ & .000033 \\
\hline A-R Wald test & 32.568 & 41.418 & 30.545 & 34.846 & 41.817 & 28.971 \\
\hline p-value & $4.6 \mathrm{e}-06$ & $7.7 \mathrm{e}-08$ & .000012 & $1.6 \mathrm{e}-06$ & $6.4 \mathrm{e}-08$ & .000023 \\
\hline Stock-Wright LM S statistic & 30.221 & 39.331 & 28.116 & 31.006 & 39.139 & 27.126 \\
\hline p-value & .000013 & $2.0 \mathrm{e}-07$ & .000035 & $9.3 \mathrm{e}-06$ & $2.2 \mathrm{e}-07$ & .000054 \\
\hline $\mathrm{K}-\mathrm{P}$ robust $\mathrm{rk}$ Wald $\mathrm{F}$ & 20.578 & 23.987 & 25.551 & 23.033 & 26.699 & 26.559 \\
\hline c.v. rel.bias $10 \%$ & 4.840 & 4.840 & 4.840 & 4.840 & 4.840 & 4.840 \\
\hline c.v. rel.bias $15 \%$ & 3.560 & 3.560 & 3.560 & 3.560 & 3.560 & 3.560 \\
\hline c.v. rel.bias $20 \%$ & 3.050 & 3.050 & 3.050 & 3.050 & 3.050 & 3.050 \\
\hline c.v. rel.bias $25 \%$ & 2.770 & 2.770 & 2.770 & 2.770 & 2.770 & 2.770 \\
\hline Shea's adj. part. R-sq & 0.109 & 0.119 & 0.158 & 0.122 & 0.131 & 0.135 \\
\hline
\end{tabular}

Notes: The table reports estimation results of regressions where the dependent is, on turn, the net total wealth minus durable goods and real estates (a), the net total wealth minus real estates $(b)$ the net total wealth (c). The dependent variable is regressed on permanent income, variance of expected income, age, age squared, risk-loving indicator, dummies for good health condition, number of children, time and regions. Columns with number 1 and 2 identify results from a specification with an alternative estimate of permanent income and income risk, respectively. "Precaut. Sav." is computed by taking the mean of the formula: $\left(1-1 / \exp \left(a_{1} * u\right)\right) * 100$. "K-P robust rk Wald F" is the Kleibergen-Paap Wald rk F statistic. c.v. rel.bias 10\%, 15\%, 20\% and 25\% are the critical values compiled by Stock et al. "Shea's adj. part. R-sq" is the Shea's partial adjusted $R$-squared. The A-R Wald $F$ and Chi2 tests and the Stock-Wright LM Statistic are overidentification tests. *, **, *** indicate coefficients are significative at 10, 5 and $1 \%$, respectively. 
Table 7: Estimation results. Alternative measures of risk aversion

\begin{tabular}{|c|c|c|c|c|c|c|}
\hline & (a1) & (b1) & (c1) & (a2) & (b2) & (c2) \\
\hline & $\begin{array}{r}\operatorname{liml} \\
\beta / \text { t-stat }\end{array}$ & $\underset{\beta / \text { t-stat }}{\operatorname{liml}}$ & $\underset{\beta / \text { t-stat }}{\operatorname{liml}}$ & $\underset{\beta / \text { t-stat }}{\operatorname{liml}}$ & $\begin{array}{r}\operatorname{liml} \\
\beta / \text { t-stat }\end{array}$ & $\underset{\beta / \text { t-stat }}{\operatorname{liml}}$ \\
\hline \multirow[t]{2}{*}{$\operatorname{Var}_{t}^{s u}\left(y_{t+1}\right) \mathrm{I}$} & $2.87 \mathrm{e}-09^{* * *}$ & $2.47 \mathrm{e}-09^{* *}$ & $3.19 \mathrm{e}-09^{* * *}$ & $1.88 \mathrm{e}-09^{* * *}$ & $1.41 \mathrm{e}-09$ & $2.40 \mathrm{e}-09^{* * *}$ \\
\hline & 3.36 & 2.33 & 3.52 & 2.59 & 1.20 & 3.61 \\
\hline $\ln ($ permanent income $)$ & $1.31^{* * *}$ & $1.24^{* * *}$ & $.924^{* * *}$ & $1.11^{* * *}$ & $1.08^{* * *}$ & $.489^{* *}$ \\
\hline risk aversion ind. II & $\begin{array}{r}5.76 \\
-.0601^{* *} \\
-2.13\end{array}$ & $\begin{array}{r}6.49 \\
-.0652^{* * *} \\
-2.66\end{array}$ & $\begin{array}{r}3.58 \\
-.041 \\
-1.60\end{array}$ & 3.90 & 4.83 & 2.07 \\
\hline risk aversion ind. III & & & & $\begin{array}{r}-.0947 \\
-1.64\end{array}$ & $\begin{array}{r}-.215^{* * *} \\
-5.05\end{array}$ & $\begin{array}{r}-.121^{* * *} \\
-3.14\end{array}$ \\
\hline good health & $\begin{array}{l}.106 \\
0.88\end{array}$ & $\begin{array}{r}.198^{*} \\
1.95\end{array}$ & $\begin{array}{r}-.00118 \\
-0.01\end{array}$ & $\begin{array}{r}.0733 \\
0.52\end{array}$ & $\begin{array}{l}.187 \\
1.57\end{array}$ & $\begin{array}{r}.165 \\
1.43\end{array}$ \\
\hline age & $\begin{array}{r}.0928 \\
0.91\end{array}$ & $\begin{array}{l}.094 \\
1.16\end{array}$ & $\begin{array}{l}.17^{*} \\
1.68\end{array}$ & $\begin{array}{r}.0995 \\
0.80\end{array}$ & $\begin{array}{r}.0528 \\
0.55\end{array}$ & $\begin{array}{l}.139 \\
1.44\end{array}$ \\
\hline age squared & $\begin{array}{r}-.000889 \\
-0.71\end{array}$ & $\begin{array}{r}-.000752 \\
-0.75\end{array}$ & $\begin{array}{r}-.00154 \\
-1.25\end{array}$ & $\begin{array}{r}-.000896 \\
-0.59\end{array}$ & $\begin{array}{r}-.000189 \\
-0.16\end{array}$ & $\begin{array}{r}-.0011 \\
-0.94\end{array}$ \\
\hline 1 child & .0229 & .0607 & $-.436^{* *}$ & -.324 & .00236 & $-.435^{* * *}$ \\
\hline \multirow[t]{2}{*}{2 children } & $\begin{array}{r}0.09 \\
-.113\end{array}$ & $\begin{array}{r}0.29 \\
-.104\end{array}$ & $\begin{array}{r}-2.57 \\
-.408 * * *\end{array}$ & $\begin{array}{l}-1.19 \\
-.354\end{array}$ & $\begin{array}{r}0.01 \\
-.175\end{array}$ & $\begin{array}{r}-2.61 \\
-.407 * * *\end{array}$ \\
\hline & -0.45 & -0.51 & -2.58 & -1.50 & -0.86 & -2.78 \\
\hline \multirow[t]{2}{*}{3 children } & -.264 & -.171 & -.239 & $-.502^{* *}$ & -.171 & -.146 \\
\hline & -1.03 & -0.82 & -1.48 & -2.05 & -0.80 & -0.99 \\
\hline Precaut. Sav. \% & 1.062 & 0.947 & 1.094 & 0.897 & 0.709 & 1.033 \\
\hline R-squared & -0.060 & -0.003 & 0.051 & 0.020 & 0.095 & 0.153 \\
\hline $\mathrm{N}$ & 2089.000 & 2334.000 & 2321.000 & 1295.000 & 1436.000 & 1430.000 \\
\hline A-R Wald test & 7.404163 & 9.305949 & 5.715427 & 3.364545 & 4.582021 & 3.513146 \\
\hline p-value & $8.0 \mathrm{e}-07$ & $1.1 \mathrm{e}-08$ & .000033 & .0052 & .0004 & .0038 \\
\hline A-R Wald test & 37.619 & 47.202 & 28.992 & 17.263 & 23.449 & 17.981 \\
\hline p-value & $4.5 \mathrm{e}-07$ & $5.2 \mathrm{e}-09$ & .000023 & .004 & .00028 & .003 \\
\hline Stock-Wright LM S statistic & 33.743 & 42.679 & 26.940 & 16.211 & 21.858 & 17.465 \\
\hline p-value & $2.7 \mathrm{e}-06$ & $4.3 \mathrm{e}-08$ & .000059 & .0063 & .00056 & .0037 \\
\hline K-P robust rk Wald $\mathrm{F}$ & 25.663 & 32.084 & 33.022 & 16.799 & 21.509 & 20.945 \\
\hline c.v. rel.bias $10 \%$ & 4.840 & 4.840 & 4.840 & 4.840 & 4.840 & 4.840 \\
\hline c.v. rel.bias $15 \%$ & 3.560 & 3.560 & 3.560 & 3.560 & 3.560 & 3.560 \\
\hline c.v. rel.bias $20 \%$ & 3.050 & 3.050 & 3.050 & 3.050 & 3.050 & 3.050 \\
\hline c.v. rel.bias $25 \%$ & 2.770 & 2.770 & 2.770 & 2.770 & 2.770 & 2.770 \\
\hline Shea's adj. part. R-sq & 0.113 & 0.119 & 0.145 & 0.126 & 0.132 & 0.137 \\
\hline
\end{tabular}

Notes: The table reports estimation results where the dependent is, on turn, the net total wealth minus durable goods and real estates (a), the net total wealth minus real estates $(b)$ the net total wealth (c). The dependent variable is regressed on permanent income, variance of expected income, age, age squared, risk-loving indicator, dummies for good health condition, number of children, time and regions. Columns with numbers 1 and 2 identify results from specifications with two alternative estimates of individual risk aversion. "Precaut. Sav." is computed by taking the mean of the formula: $\left(1-1 / \exp \left(a_{1} * u\right)\right) * 100$. "K-P robust rk Wald $F "$ is the Kleibergen-Paap Wald rk F statistic. c.v. rel.bias 10\%, 15\%, 20\% and 25\% are the critical values compiled by Stock et al. "Shea's adj. part. R-sq" is the Shea's partial adjusted R-squared. The A-R Wald F and Chi2 tests and the Stock-Wright LM Statistic are overidentification tests. *, **, *** indicate coefficients are significative at 10, 5 and $1 \%$, respectively. 


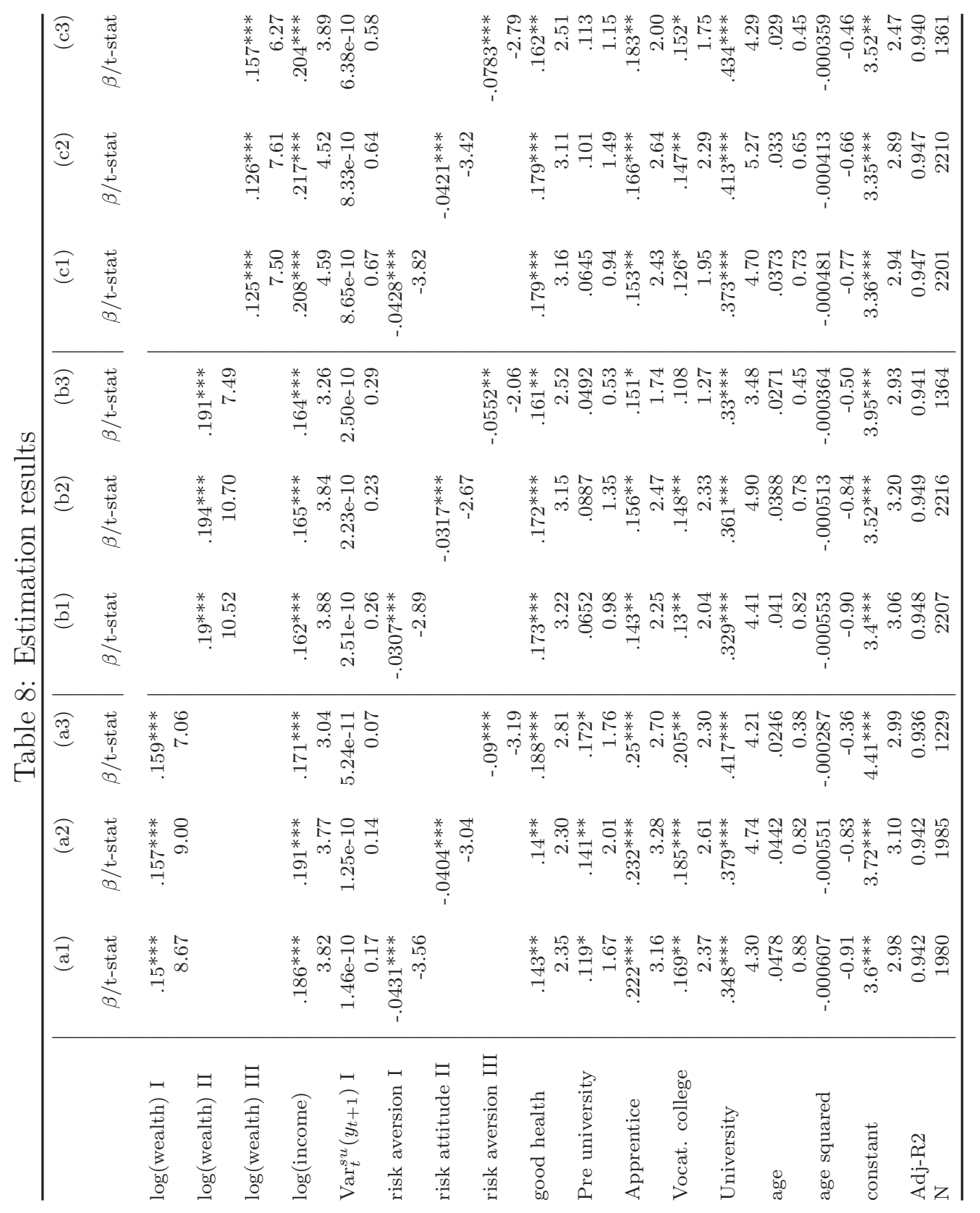

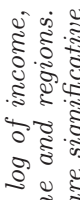

है है

उ.

8 웡

जू हैं

क्ष

के क*

त है

है. है.

ชี

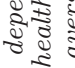

जी:

हैं है

क. ङ

웛 हैँ

可

늉. है

ชั้

ช. है

ज.

इँ

S)

है

क्षे

हี

व हैं

क. 해

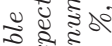

ㄴำ

है है की

कु. है हैं 

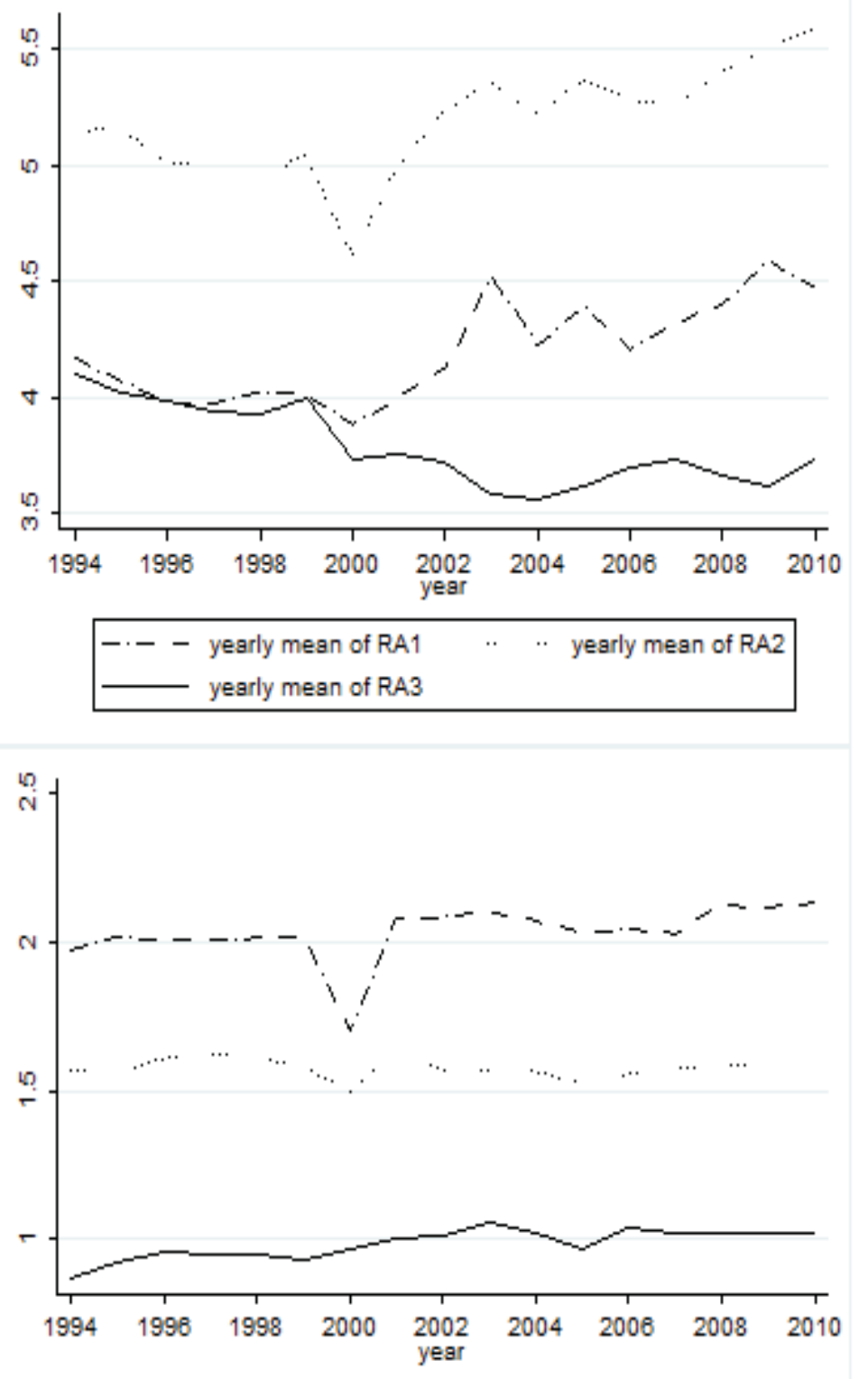

- - - - yearly standard deviation of RA1 $\cdots \quad \cdots \quad$ yearly st. dev. RAZ yearly standard deviation of RA3

Figure 1: Yearly means and standard deviations of risk aversion indicators 


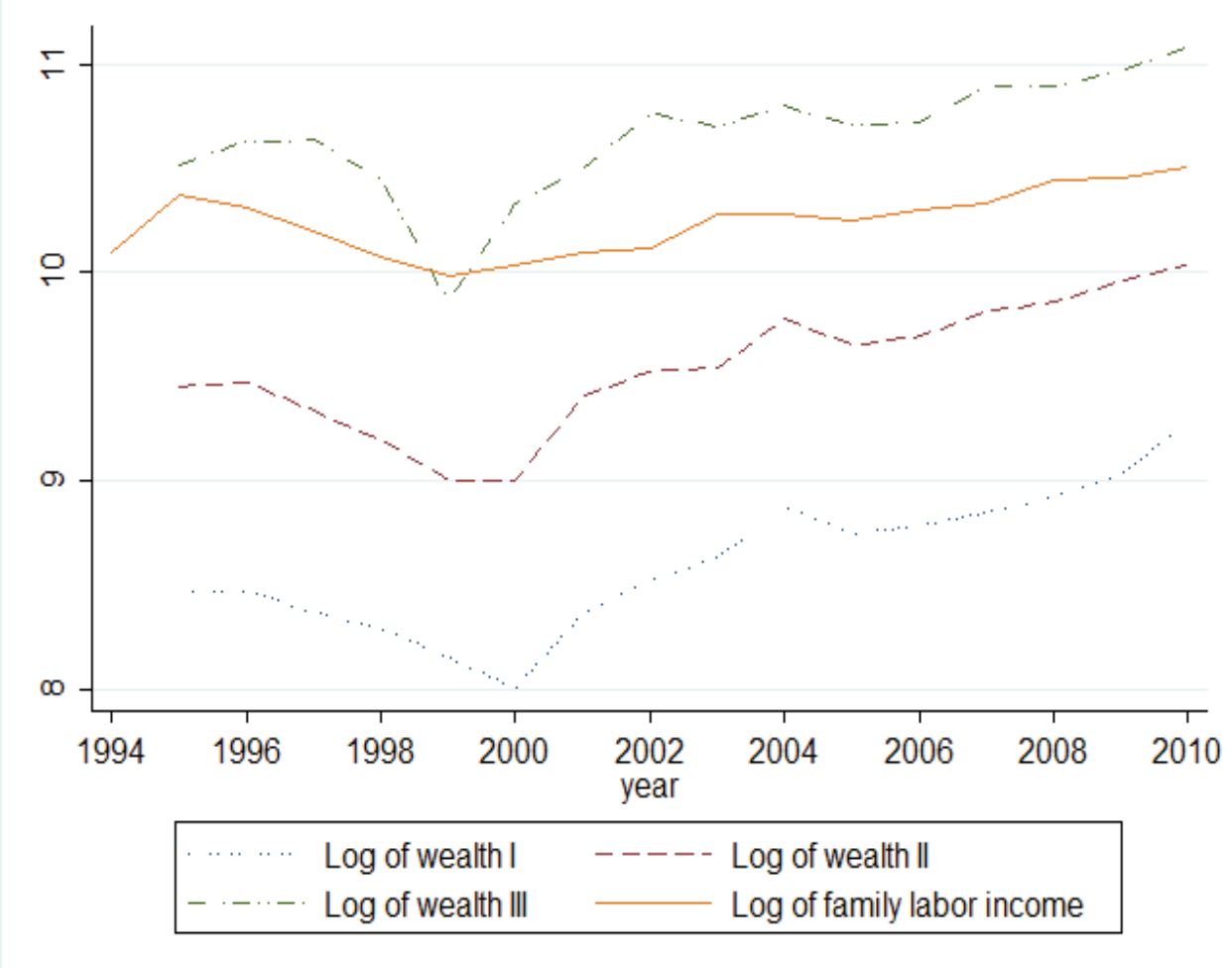

Figure 2: Yearly means of wealth and income 